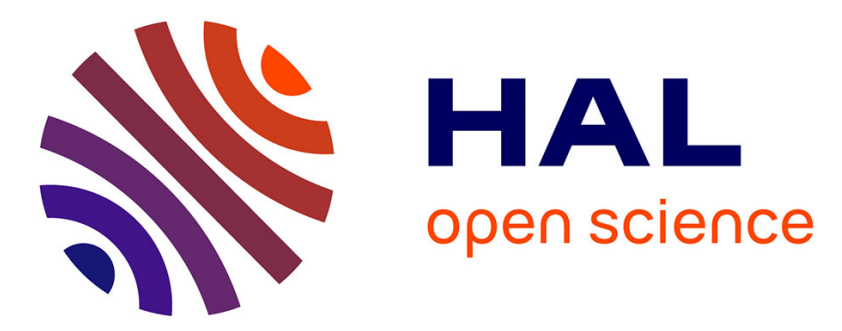

\title{
Teacher perceptions of science in the National Curriculum: findings from an application of the Science Curriculum Implementation Questionnaire in English primary schools \\ John Sharp
}

\section{To cite this version:}

John Sharp. Teacher perceptions of science in the National Curriculum: findings from an application of the Science Curriculum Implementation Questionnaire in English primary schools. International Journal of Science Education, 2011, pp.1. 10.1080/09500693.2010.550698 . hal-00693828

\section{HAL Id: hal-00693828 \\ https://hal.science/hal-00693828}

Submitted on 3 May 2012

HAL is a multi-disciplinary open access archive for the deposit and dissemination of scientific research documents, whether they are published or not. The documents may come from teaching and research institutions in France or abroad, or from public or private research centers.
L'archive ouverte pluridisciplinaire HAL, est destinée au dépôt et à la diffusion de documents scientifiques de niveau recherche, publiés ou non, émanant des établissements d'enseignement et de recherche français ou étrangers, des laboratoires publics ou privés. 


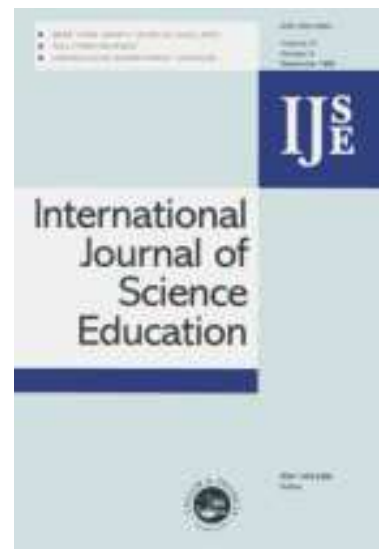

Teacher perceptions of science in the National Curriculum: findings from an application of the Science Curriculum Implementation Questionnaire in English primary schools

\begin{tabular}{|r|l|}
\hline Journal: & International Journal of Science Education \\
\hline Manuscript ID: & TSED-2010-0305-A.R1 \\
\hline Manuscript Type: & Research Paper \\
\hline Keywords : & \\
\hline Keywords (user): & primary science, curriculum implementation, teacher perceptions, \\
\hline
\end{tabular}

\section{SCHOLARONE}

Manuscripts 


\title{
Teacher perceptions of science in the National Curriculum: findings from an application of the Science Curriculum Implementation Questionnaire in English primary schools
}

\author{
John G. Sharp ${ }^{1}$ \\ Rebecca Hopkin ${ }^{1}$ \\ Brian Lewthwaite ${ }^{2}$ \\ ${ }^{1}$ Bishop Grosseteste University College Lincoln \\ Newport \\ Lincoln LN1 3DY \\ UK \\ ${ }^{2}$ University of Manitoba \\ Winnipeg \\ Manitoba R3T 2N2 \\ Canada
}

Please direct all correspondence to the first author, Professor John G. Sharp

This article is protected until released for publication

C Sharp, Hopkin and Lewthwaite November 2010 


\title{
Teacher perceptions of science in the National Curriculum: findings from an application of the Science Curriculum Implementation Questionnaire in English primary schools
}

\begin{abstract}
This article presents and discusses outcomes arising from a recently completed National Primary Science Survey (England) intended, in part, to elicit how teachers and others perceive the effectiveness of colleagues and the schools in which they work to implement and deliver primary science within the National Curriculum. While the majority view among respondents was found to be generally positive and encouraging, particularly so in terms of school ethos and regard for science as a curriculum area, certain personal or 'intrinsic' and environmental or 'extrinsic' elements were nevertheless identified as more inhibiting than others and for certain subgroups within the sample of participants itself. The majority of findings reported here were obtained using a 7-scale, 49-item diagnostic research instrument originally developed for use in New Zealand and subsequently transported to other locations around the world. In its first fully documented use within the UK, the validity, reliability and potential of this instrument to provide teachers and others with a means of evaluating science education provision together with providing an evidence-base for professional dialogue, strategic planning and decision making for overall school improvement is considered.
\end{abstract}

Key words: primary science, curriculum implementation, teacher perceptions, questionnaire survey 


\section{Introduction and general background}

From the elementary schools of the late 1800s to the primary schools of today, science has always played some part in the formal education of young children throughout the UK (Layton 1973; Richards and Holford 1983). In England alone, and over the past 25 years or so in particular, however, the rate of educational reform which has brought about the development of science education from a base rooted essentially in nature studies to a statutory 'core' subject within a much larger National Curriculum of subjects has been 'breathtaking'. So 'breathtaking', perhaps, that there have been four 'final' versions of science within the National Curriculum (DES/WO 1989, 1991; DfE/WO 1995; DfEE/QCA 1999) and the 'struggle' to formulate it since even before its first introduction has been well documented (comprehensive reviews in Oakley 1993; Black 1995a,b; Ritchie 1996, Author and Grace 2004)

Despite its immediate educational impact and some of the early achievements and apparent successes attributed to introducing science within the National Curriculum (Fortune et al. 1993; HCEC 1995; Ofsted 2002), primary teachers in England, and in all other home countries experiencing educational reforms of their own, continue, it would appear, to find themselves professionally 'challenged', particularly in relation to their own science-specific curricular expertise, going about the day to day business of transforming policy into practice, and remaining current (Russell et al. 1995; Ritchie 1996; Boyle and Bragg 2005; Ofsted 2008). With the benefit of hindsight, of course, this should come as no surprise given the generally low status of primary science relative to other subject areas reported earlier in the National Primary Survey of Schools (DES 1978) and work of the Assessment of Performance Unit (DES/WO/DENI 1988) and the simple and obvious fact that most practitioners working with the National Curriculum for the first time had little experience of science beyond what they themselves had encountered at school. With a 'tool kit' of sometimes highly specialised professional knowledge and skills increasingly in demand, addressing and acquiring curricular expertise in science has always proved somewhat problematic, particularly for the 'generalist' primary teacher (Sorsby and Watson 1993), often resulting in the almost unavoidable adoption of coping strategies not all of which could be considered productive (Summers 1994; Harlen and Holroyd 1997; Newton and Newton 2000; Pine et al. 2001). A lasting solution through pre-service and in-service education and training and continuous professional development has always remained somewhat elusive (Kruger et al. 1990; Kinder and Harland 1991; Summers and Kruger 1994; Smith 1999; 
Qualter 1999; Pell and Jarvis 2003; Jarvis et al. 2003; Ryan 2003; Traianou 2006). Teachers' limited subject knowledge of science in particular was quickly identified as a major factor adversely impacting on 'delivery' (planning, teaching, differentiation and assessment) as well as confidence in the classroom and ultimately the range and quality of children's learning experiences (Russell et al. 1992; Summers 1992; Holroyd and Harlen 1996; Osborne and Simon 1996) and subject knowledge subsequently received considerable attention. With an emphasis on subject knowledge keenly debated, most recent attention has moved away from attempting to tackle subject knowledge, effectively in isolation, to considering effective strategies for the integration of subject, pedagogical content and curricular knowledge developed from working with teachers themselves, or those in training, and within their own communities of practice (e.g. Parker and Heywood 1998, 2000; Shallcross and Spink 2002; Parker 2004;). Similarly, work continues to positively influence primary teachers' personal beliefs and attitudes towards science, and about the nature of science, which also affect the many ways in which science is regarded and presented (Parker and Spink 1997; Abd-El-Khalick and Lederman 2000; Lunn 2002; Pell and Jarvis 2003; Waters-Adams 2006). Integrating science within the professional identities of primary teachers has proved no easy task.

The issues identified, raised and discussed across England, and throughout the rest of the UK, have also been widely observed internationally where science education is a formal area of the primary school curriculum (Abell and Lederman 2007). Indeed, the dynamics and conditions leading to the development of proposed 'national curricula' within, for example, the United States, beginning with 'Project 2061 Benchmarks' and the 'National Science Education Standards' (AAAS 1993; NRC 1996), now the 'Common Core State Standards Initiative' (NGA/CCSSO 2010), and the first introduction of science in the National Curriculum of New Zealand (MoE 1993; now MoE 2007), all bear striking similarities to those matters closer to home, albeit with their own culture-specific idiosyncrasies and important departures of experience. With progress over time very much in evidence at the 'chalk-face' (Author et al. 2009), moves to further reform the entire primary curriculum in England are already underway (Rose 2009), though with the introduction of a new Government in 2010 the exact impact on primary science will probably not be known for some time.

In this article, we attempt to provide insight into where teachers believe they themselves 'are' with primary science implementation today, building on previous work, and perhaps providing something of a benchmark for future comparative studies. In order to achieve this, full use was made of a 7-scale, 49-item diagnostic research instrument, the Science Curriculum Implementation Questionnaire (SCIQ), originally developed for use in New 
Zealand and subsequently transported to other locations around the world (Author and Fisher 2005).

\section{Curriculum evaluation}

Surprisingly few national evaluations of science within the National Curriculum have ever been undertaken. Perhaps two of the most well known, and which provided the broad framework and stimulus for our own National Primary Science Survey (England), itself incorporating the Science Curriculum Implementation Questionnaire (SCIQ), are briefly described.

In the longitudinal Leverhulme Primary Project, which operated between 1989 and 1993, researchers at Exeter University explored the early impact of the National Curriculum in a questionnaire survey of 901 primary teachers from 152 English and Welsh schools (Wragg et al. 1989). In brief, and while found to be in an initial state of stress and apprehension though responding with enthusiasm, the implementation of requirements was found to vary widely from class-to-class and school-to-school. Results from the ten different National Curriculum subject areas taught at that time nevertheless indicated that teachers perceived themselves to be best equipped to teach English (81\% feeling competent) and mathematics (68\% feeling competent), with science (only $34 \%$ feeling competent) ranked eighth ahead of only music and design and technology. In the exploration of specific elements within the science curriculum itself, teaching of the more physical components was less well favoured than the more biological (Carré and Carter 1990). The follow-up phase of the Leverhulme Primary Project involved the participation of 433 teachers in 131 schools, $43 \%$ of which had been involved earlier (Bennett et al. 1992). Administration of the original questionnaire, with only minor alterations, allowed the researchers to investigate what, if any, progress had taken place. Even over the short timeframe involved, a general picture of potential adjustment and accommodation had emerged. Results again indicated that teachers perceived themselves best equipped to teach English (77\% feeling competent) and mathematics (62\% feeling competent) but science had leapt up to third (still only $41 \%$ feeling competent). The researchers highlighted that while lots of 'activity' was going on, whether or not the best or even the right kind of science was being taught remained open to question (Carré and Carter 1993).

Much later, and following a Parliamentary Office for Science and Technology report highlighting continued concerns over primary science and teachers' curricular expertise (PoST 2003), the Wellcome Trust funded the Primary Horizons project aimed at exploring 
teachers' experiences of science across all four home countries of the UK and identifying areas for improvement (Murphy et al. 2005, 2007). Findings from the project's telephone, email, focus group survey and cross-sector consultation revealed that even following long periods of adjustment and accommodation related to their own national phases of educational reform, certain aspects of primary science continued to impact adversely upon implementation and delivery. From the telephone survey alone, which included up to 150 teachers from England and 150 more from within Scotland, Wales and Northern Ireland, the concerns raised from the study included:

- a general lack of knowledge and expertise as well as training, and therefore confidence in order to teach primary science effectively (50\% of respondents);

- the sometimes poor availability, access to and use of resources, including resource funding (33\% of respondents);

- the lack of time available to prepare for and teach science, particularly in relation to English and mathematics (20\% of respondents);

- an overloaded curriculum, both generally across all subjects and within science itself ( $17 \%$ of respondents);

- sometimes prohibitively large class sizes, and classrooms with space restrictions ( $11 \%$ of respondents);

- a lack of in-class support, mainly in the form of classroom assistants (4\% of respondents).

The study also highlighted a mismatch in perception between what teachers thought they were capable of teaching and what children found easy or difficult to learn, the narrow and focused use of assessment to test little more than recall rather than open-ended investigation, and the challenges attached to the use of ICT to support science. On a positive note, the majority of teachers involved also recognised that science education should stimulate enthusiasm and interest among young children, be as relevant to their everyday lives as possible, and address thinking skills. Only by achieving these things did respondents consider that scientific literacy could be improved. Taken together, the project team set out something of a clear and evidence-based agenda, at least in their own minds, intended for the attention and consideration of policy makers and budget holders alike. Among the possible solutions proposed for taking primary science forward included making continuing professional development via in-service training more available, and making better use of 'creative contexts' for science such as field trips, role play, stories and 
incorporating history. It was also felt that better use could be made of science specialist teachers and external experts.

While both the Leverhulme Primary and the Primary Horizons projects both exhibit limitations and shortcomings inherent in their overall designs, methodologies and conclusions, features by no means unique to them, both also betray something of an entirely understandable sense of a profession 'swimming against a tide' of reform, the drivers for which have always been more political than educational and often with little regard for research (Brighouse and Moon 1990; Barber and Graham 1993; Kelly 1994; Harlen 1992; Lawton 1992; Moon 1994). Importantly, both focused more on which remedial steps might be taken to improve classroom practice than set out to challenge the very philosophical, theoretical and ideological underpinnings of the curriculum itself. What they both reinforce convincingly, however, is the view expressed by Fullan (1992) who indicated that the success of curriculum implementation and delivery is influenced by many complexly interrelated and systemic features and that no one alone can be targeted to effect change and improvement. It is to this we now turn our attention.

\section{Current study: the National Primary Science Curriculum (England)}

The work presented and discussed here was undertaken as part of the National Primary Science Survey (England), a research initiative intended to make a further contribution towards informing curriculum debate at the highest level and to begin to identify steps to better understand the nature of science education provision in this one country alone (Authors 2007; Author et al. 2009). Guided by the Leverhulme Primary Project of the late 1980s and early 1990s and the Primary Horizons project, this included an exploration of how well teachers perceived the capacity of their own schools to implement and deliver science as it appeared in the National Curriculum of England at the time (DfEE/QCA 1999). A particular focus lay in identifying those factors impeding or contributing to progress and penetrating further and deeper into some of the areas investigated by the Primary Horizons project, measuring and quantifying the 'direction' and 'strength' of 'feeling' within the primary profession more accurately.

As part of the NPSS (England), 600 primary schools were randomly sampled from the initial teacher training partnership clusters of six Higher Education institutions, each cluster selected purposively from across several geographically distinct regions of the country and surrounding the cities of Lincoln, Liverpool, Sheffield, Bath, Exeter and Hull. Those schools were each provided with previously trialled NPSS (England) documentation in anticipation 
that the head teacher, science co-ordinator and at least one class teacher would respond, maximising response rate opportunity and providing the widest possible range of views from within the profession as sampled as a whole. Overall, 303 primary practitioners from 206 schools participated (a $34.3 \%$ school response rate and $16.8 \%$ participant response rate). Response rates varied by region with 97 returns from 65 schools the highest (the Lincoln cluster) to 23 returns from 14 schools the lowest (the Bath cluster). While participants working across the entire primary age range at all levels were ultimately involved, readers should be mindful of issues surrounding the representativeness of the sample of schools together with the typicality of the data collected.

\section{Sample background}

Summary characteristics of the sample are provided as shown (Table 1). Of the 303 respondents, 246 (81.2\%) were female and 57 (18.8\%) were male. For the purposes of this work, non-teaching deputies were grouped with head teachers, and teaching deputies were grouped with science coordinators or class teachers depending on the exact nature of their teaching role. Respondents presented a wide range of teaching qualifications including, in addition to those listed, six MEds, one PhD and twelve NPQHs. While 75 (24.8\%) respondents indicated that they had specialised in primary science during initial teacher training, $82(27.1 \%)$ were designated science coordinators with a further $2(0.7 \%)$ holding shared responsibility for science within their broad remit of curriculum responsibilities. Only $30(9.9 \%)$ respondents held a first degree in science (respondents were invited to specify but few did). All other areas of curriculum specialisation and responsibility were represented. $15(5.0 \%)$ respondents were newly qualified teachers while $55(18.2 \%)$ had been teaching for over 25 years. Almost equal numbers of respondents had been teaching for up to or over 10 years (0-10 years 138 or $45.5 \%$, over 10 -years 165 or $54.5 \%$ ). Again, and for the purposes of this work, this division marks a significant period in time during which the initial teacher training requirements in England were radically overhauled themselves and a centrally imposed national science curriculum for teachers addressing subject knowledge, pedagogical content knowledge and assessment methods introduced (DfEE Circular 4/98 1998). Prior to this, the training requirements for science were less rigid and prescriptive (the requirements specified in DfEE Circular 4/98 were later relaxed though widely referred to for guidance for some time). The majority of respondents worked in primary schools (261, $86.1 \%)$ teaching across all year groups from reception to Year 6. $188(62.1 \%)$ schools were considered large, with over 200 pupils enrolled, and 115 (37.9\%) were considered small, with up to 200 pupils enrolled. In-service uptake among teachers within the schools or with 
local authorities in the three years prior to the survey was good $(121,39.9 \%)$ but attendance at Science Learning Centres was poor (15, 5.0\%).

\section{[Insert Table 1 as close to here as possible.]}

\section{Confirmatory analyses: the Science Curriculum Implementation Questionnaire (SCIQ)}

Embedded within the research framework of the NPSS (England) was the 7-scale, 49-item diagnostic research instrument considered appropriate for the level of systemic insight required (see Owens 1995). This Science Curriculum Implementation Questionnaire (SCIQ), is presented in full as shown (Appendix 1). The development of the SCIQ by Author and Fisher (2005) took place in two main stages. Initially, personal and environmental attribute factors influencing delivery of the New Zealand science curriculum were identified among 122 practising and 144 pre-service teachers, with one school-based case study and an extensive review of literature. These were subsequently transformed into a collection of usable questionnaire items responded to with a 5-point, Likert-type scale (strongly agree $=5$ to strongly disagree $=1$, with some reverse-score items included) and grouped into a small number of readily identifiable categories by 6 primary practitioners working in different capacities within the New Zealand education system. The emergent questionnaire was then trialled with a further 293 teachers and subjected to rigorous statistical analysis to determine validity and reliability. The final version of the SCIQ included 3 scales reflecting the personal or 'intrinsic' factors (professional knowledge, professional attitude and interest, professional adequacy) and 4 reflecting environmental or 'extrinsic' factors (professional adequacy, resource adequacy, time, school ethos, professional support). Further details are provided as shown (Table 2).

\section{[Insert Table 2 as close to here as possible.]}

Several international research projects conducted not only in New Zealand but in Canada and Iceland provide evidence of the versatility of the SCIQ for supporting the diagnostic evaluation of science education provision at school and for monitoring the professional development and effectiveness of primary teachers locally, regionally and nationally (Payne and Author 2002; Author and Fisher 2004; Author 2005, 2006; Macdonald 2008). The SCIQ has also served as the foundation for the development of several other science curriculum evaluation instruments specific to settings in which the aspirations for science education and influences on the realisation of these aspirations are more complex than mainstream 
settings. These include francophone-minority and Inuit settings also in Canada (Author, Stoeber and Renaud 2007; Author and Renaud 2009).

Minor changes to the language and terminology of certain items within the SCIQ, and the import of an instrument developed for use in a different cultural context to the UK, prompted a necessary reassessment of instrument's validity and reliability using the data obtained during the NPSS (England). This was also considered appropriate given its first 'outing' in the UK. The procedures adopted by Author and Fisher (2005) were replicated as closely as possible and entailed:

- determination of the construct validity of the 7 scales by exploring patterns among the 49 items using principal component analysis;

- determination of the discriminant validity or degree of independence of each scale;

- determination of the internal consistency or reliability of each scale using Cronbach's alpha.

All outcomes are presented as shown (Table 3).

\section{[Insert Table 3 as close to here as possible.]}

\section{(i) Principal component analysis}

Principal component analysis is a statistical technique commonly used in questionnaire design to establish construct validity. In other words, it helps to simplify and understand the structure of a set of variables by identifying where these cluster and possibly measure the same underlying factor. A preliminary exploration of the SCIQ data identified that the basic requirements of principal component analysis were satisfied confirming that this was a suitable approach (K-M-O=0.95; Bartlett's sphericity $\chi^{2}=11261.57, \mathrm{df}=1176, \mathrm{p}<0.001$ ). Under varimax rotation, a five component solution explaining $62.1 \%$ of the variance was accepted. In this solution, all 21 items of the three 'intrinsic' scales (professional knowledge, professional attitude and interest, professional adequacy) clustered almost exclusively on the same single component while the remaining items clustered on the four remaining components and in almost perfect association with their respective 'extrinsic' scales (professional science adequacy, resource adequacy, time, school ethos, professional support). All rotated factor loadings associated with the 5 components were greater than 0.400 . Typically, a factor loading greater than 0.400 is considered significant (Field 2009). 
Discriminant validity considers the degree of independence of questionnaire scales. In other words, it helps reveal the extent to which different scales overlap. Values across all 7 scales ranged from 0.385 (time) to 0.631 (professional adequacy). Typically, values greater than 0.850 suggest strong overlap and a suggestion that scales are measuring the same phenomena (Field 2009). Values for the three 'intrinsic' scales (0.616 to 0.631) were higher than the four 'extrinsic' scales (0.385 to 0.572). Simple inter-scale correlations revealed the 'intrinsic' scales to have the highest degree of correlation also (0.797-0.847). Taken together, it would seem reasonable to assume a moderate degree of overlap and interdependence between the 'intrinsic' scales not observed in the 'extrinsic' scales, but that the 'intrinsic' scales preserve something of their individual integrities.

\section{(iii) Cronbach's alpha}

Cronbach's alpha considers the internal consistency or reliability of questionnaire scales. In other words, it helps to determine whether or not the items in a scale consistently reflect the construct being measured. Values across all 7 scales ranged from 0.833 (professional adequacy) to 0.915 (time). Typically, values greater than 0.700 are considered significant (Field 2009). For all 7 scales, the deletion of any single item caused no substantial increase in the alpha coefficient confirming the outcome. Item-total correlation values across all 7 scales ranged from 0.303 (professional adequacy) to 0.833 (time) with average item-total correlation values ranging from 0.629 to 0.750 . Typically, values greater than 0.300 are considered significant (Field 2009). Overall, a high level of internal consistency or reliability of the 7 scales was noted.

(iv) Fitness for purpose

Validity and reliability outcomes for the SCIQ were surprisingly similar to those reported by Author and Fisher (2005), including the emergence of a five rather than expected seven component solution. The SCIQ, slightly modified for use within the UK as indicated, showed every sign of having transported from one cultural context to another remarkably well. The personal attribute dimensions reflected in the three 'intrinsic' scales may be indistinguishable 
statistically, as determined by the principal component analysis of data, but each retains a degree of individual integrity and remains of considerable value and importance educationally. While it could reasonably be argued that retaining the three separate 'intrinsic' scales is a weakness in the overall construction of the SCIQ, at worst calling into question the security of any findings obtained from it, it could also be reasonably argued that their retention reflects the inextricable links and challenges that disentangling curricular expertise presents (Kind 2009). For the purposes of this study, the scales, as the individual items within them, are of professional significance and an educational rather than statistical interpretation received greater weight. The environmental or 'extrinsic' scales were less problematic and measured independent factors more clearly.

Statistical modelling with educational interpretation suggested that the instrument was generally 'fit' for the purpose intended. One important feature to note within the SCIQ, however, is the integration of subject, pedagogical content and curricular knowledge into the one professional knowledge scale. Though not a weakness of the questionnaire or the professional knowledge scale per se (see later exploratory analyses), the task of probing science as one of twelve subject areas of the National Curriculum together with all thirteen elements of the science programmes of study was carried out within the NPSS (England) independently. In relative terms, science fell into an 'improved' third place behind English and mathematics as it had in the past with $60.7 \%$ feeling sufficiently well prepared with existing knowledge and skills not to have to rely on any further help from colleagues or inservice support $(71.9 \%$ for English and $70.6 \%$ for mathematics). Interestingly, while $90.8 \%$ of respondents indicated that they enjoyed teaching science in general, only $18.2 \%$ specifically highlighted science as the area of the curriculum they enjoyed teaching the most - fewer than the number of actual science co-ordinators. Findings associated with the thirteen elements of the science programmes of study are presented as shown (Table 4) with the more biological components of the curriculum continuing to lead over the more physical (see Author et al. 2009 for full details).

[Insert Table 4 as close to here as possible.]

\section{Exploratory analyses}

In this and in the following sections, responses associated with each of the 7 scales are considered at different levels of detail beginning with an overview provided as shown (Table 5). While common practice to routinely summarise and report data obtained from questionnaires such as the SCIQ using mean and median scores, standard deviations, and 


\section{[Insert Table 5 as close to here as possible.]}

Findings were generally positive and encouraging with over $80 \%$ of all scores across the 7 items of some scales expressing agreement or strong agreement (e.g. school ethos and professional attitude and interest). While lower in others, the levels of expressed agreement or strong agreement remained relatively impressive (e.g. time at $58.8 \%$ and professional support at $67.1 \%$ ). Overall, mean scale values ranged from 3.56 (time) to 4.07 (school ethos) on the 5-point scale, while median values ranged from 3.71 (time) to 4.14 (school ethos). Interestingly, the variation in responses reflected in standard deviations appeared 'tighter' for the 'intrinsic' scales than the 'extrinsic' scales suggesting some uncertainty in views at least between the personal and environmental factors. The significance of time as most impeding the implementation and delivery of primary science was further emphasised with this scale receiving the highest expressed level of disagreement or strong disagreement $(16.7 \%)$. The relatively moderate numbers of 'neutral' views provided should not be overlooked (16.2\% to $25.0 \%)$. What seems to emerge from this first level of analysis is a picture of participating schools with largely enthusiastic and motivated staff displaying a relatively high regard for primary science and its status while flagging up issues associated with the demands attached to preparing for and teaching science as a curriculum area.

In order to better visualise the differences between them, scores are also presented in the form of box and whisker plots (Fig.1). Though perhaps looking 'slight' in appearance, observed differences across all 7 scales were statistically significant (Friedman's $\chi^{2}=222.6$, $\mathrm{df}=6, \mathrm{p}=0.000$ ). Significant differences were also observed across the 3 'intrinsic' scales (Friedman's $\chi^{2}=107.4, \mathrm{df}=2, \mathrm{p}=0.000$ ) and 4 'extrinsic' scales (Friedman's $\chi^{2}=111.7, \mathrm{df}=3$, $\mathrm{p}=0.000$ ). As with all surveys of this type, however, the devil is often found in the detail. 


\section{[Insert Fig. 1 as close to here as possible.]}

\section{The personal or 'intrinsic' scales \\ (i) Professional knowledge}

This scale considered curricular expertise in the form of subject matter knowledge, pedagogical content knowledge and curriculum knowledge (items 1,8,15,22,29,36,43). The scale's mean score, the lowest of the three personal or 'intrinsic' scales, was 3.83 (median 3.86). $72.5 \%$ of responses to the 7 individual items of this scale indicated agreement or strong agreement with only $3.7 \%$ disagreement or strong disagreement. The two items receiving the highest mean score were items 1 and 43 (understanding of science knowledge, skills and attitudes to be promoted, understanding of the curriculum: mean=4.07). Respondents also agreed or strongly agreed mostly with item $43(n=261,86.2 \%)$. The item receiving the lowest mean score was item 15 (alternative ways of teaching scientific ideas: mean=3.51), the same item receiving most disagreement and strong disagreement $(n=30$, $9.9 \%$ ). Overall, it might be suggested that respondents identified strengths in the curriculum knowledge of colleagues with most weaknesses in pedagogical content knowledge. Subject knowledge occupied the middle ground. This was perhaps reflected in comments attracted from the wider NPSS (England) relating directly to specific areas of the science curriculum (e.g. physical processes):

'This is my area of least knowledge and training.'

'l've never taught it before and lack experience.'

'I am not very good at thinking of things to investigate, other than setting up experiments to prove something.'

(ii) Professional attitude and interest

This scale considered perceived attitude, interest, motivation and desire to teach primary science (items $2,9^{r}, 16,23,30,37,44$ ). The scale's mean score, the highest of the three personal or 'intrinsic' scales, was 4.02 (median 4.00). $81.1 \%$ of responses to the 7 individual items of this scale indicated agreement or strong agreement with only $2.7 \%$ disagreement or strong disagreement. The item receiving the highest mean score was reverse-score item 9 ('no' reluctance to teach science: mean $=4.17$ ) while respondents mostly agreed or strongly agreed with item 37 (positive attitude to science: $n=263,86.8 \%$ ). The item receiving the 
'Science is taught in a rather dull way that doesn't motivate me or the children.' 'It lacks excitement, the content is dry. 'Teachers need more training offered about interesting ways to put across the science curriculum.'

(iii) Professional adequacy

This scale considered confidence and preparation to teach primary science effectively (items $4,11,18,25,32,39^{r}, 46^{r}$ ). The scale's mean score was 3.87 (median 3.86 ). $72.5 \%$ of responses to the 7 individual items of this scale indicated agreement or strong agreement with only $5.3 \%$ disagreement or strong disagreement. The item receiving the highest mean score was reverse-score item 46 ('positive' self-image of themselves: mean=4.09) while respondents mostly agreed or strongly agreed with item 18 (competent teachers of science: $\mathrm{n}=242,79.9 \%$ ). The item receiving the lowest mean score was item 32 (positive perceptions of competence: mean=3.68) while respondents mostly disagreed or strongly disagreed with reverse-score item 39 ('adequately' prepared to teach to requirements: $n=59,19.5 \%$ ). Overall, it might be suggested that most respondents felt that colleagues were competent and sufficiently well prepared to teach primary science and had a positive self-image of themselves regarding their ability to do so. For some, however, a lack of confidence in others was very much in evidence. Comments attracted from the wider NPSS (England) included:

'Train science co-ordinators so they are more confident. Encourage science specialists into primary education.'

'Provide science consultants to support science in schools, in a similar way to literacy and numeracy consultants that we have now.'

\section{The environmental or 'extrinsic' scales}

(i) Resource adequacy 
This scale considered the value and usefulness of existing equipment and facilities for teaching science (items $3,10,17,24,31^{r}, 38,45$ ). The scale's mean score was 3.83 (median 4.00). $71.8 \%$ of responses to the 7 individual items of this scale indicated agreement or strong agreement with only $8.9 \%$ disagreement or strong disagreement. The two items receiving the highest mean scores were items 17 and reverse-score item 31 (ready access to resources, resources 'well' organised: mean=4.03). Respondents also mostly agreed or strongly agreed with item $17(n=247,81.5 \%)$. The item receiving the lowest mean score was item 10 (resources well maintained: mean=3.64) while respondents mostly disagreed or strongly disagreed with item 45 (adequate science equipment: $n=31,10.2 \%$ ). Overall, it might be suggested that most respondents felt that their schools provided ready access to the materials and resources required to teach primary science and that these resources were, on the whole, well organised. However, some reservations concerning the nature and amount of resource available and the school-based systems for managing them were noted. Comments attracted from the wider NPSS (England) included:

'This is a difficult area to conduct and teach well due to lack of resources.'

'We require more money in the budget to improve the quality, quantity and variation of resources in order to enable more experimentation, exploration and excitement.'

'Resources take a lot of preparation and are unreliable.'

(ii) Time

This scale considered time for the preparation and teaching of science (items $\left.6^{r}, 13,20^{r}, 27,34,41,48^{r}\right)$. The scale's mean score, the lowest of the four environmental or 'extrinsic' scales and the 7 scales overall, was 3.56 (median 3.71). Only 56.8\% of responses to the 7 items of this scale indicated agreement or strong agreement with $16.7 \%$ disagreement or strong disagreement. The item receiving the highest mean score was item 41 (time for delivery of requirements: mean=3.64) while respondents mostly agreed or strongly agreed equally with items 13 and 41 (time to do an adequate job: $n=190,62.7 \%$ ). The item receiving the lowest mean score was reverse-score item 6 ('time' to fit science in properly: 3.46), item 6 also attracting most disagreement or strong disagreement $(n=68$, $22.5 \%$ ). Overall, it might be suggested that time issues and curriculum over-crowding were felt to be particularly problematic in the minds of a great many respondents but that schools generally devoted enough time in the school week to do an adequate job of effectively teaching the requirements of the science curriculum. Comments attracted from the wider NPSS (England) included: 
'Setting up practical activities is time consuming, I have no support for this.'

'Allow the time constraints and pressures placed on all other subjects, especially literacy, to be lifted, allowing children to explore the world around them and fully understand scientific concepts.'

'Provide more time for staff to prepare and explore the science curriculum.'

(iii) School ethos

This scale considered beliefs towards and regard for science as a curriculum area (items $\left.5,12,19,26,33^{r}, 40,47\right)$. The scale's mean score, the highest among the four environmental or 'extrinsic' scales and the 7 scales overall, was 4.07 (median 4.14). $80.2 \%$ of responses to the 7 individual items of the scale indicated agreement or strong agreement with only $3.6 \%$ in disagreement or strong disagreement. The item receiving the highest mean score was item 5 (management recognition of the importance of science: mean=4.30) while respondents mostly agreed or strongly agreed with item 47 (science regarded as important in the curriculum: $n=268,88.5 \%$ ). The item receiving the lowest mean score was item 26 (science has high profile: mean=3.85) while respondents mostly disagreed or strongly disagreed equally with items 12 and 19 (ethos positively influences teaching science, strong emphasis on science: $n=15,5.0 \%$ ). Overall, it might be suggested that respondents felt that the senior management of schools and the teaching staff recognised the importance and status of science as a core subject in the overall school curriculum but that science might occasionally benefit from having a stronger emphasis and higher profile. Comments attracted from the wider NPSS (England) included:

I feel that science education provision is excellent within this school, if anything needed to be improved we would highlight it as a whole school issue.'

(iv) Professional support

This scale considered the support and professional development opportunities available to teachers from both school and external sources $(7,14,21,28,35,42,49)$. The scale's overall mean score was 3.77 (median 3.86). $67.1 \%$ of responses to the 7 individual scale items of this scale indicated agreement or strong agreement with $7.9 \%$ disagreement or strong disagreement. The item receiving the highest mean score was item 42 (management actively supports science: mean=4.12), the same item receiving most agreement or strong agreement ( $n=255,84.2 \%$ ). The item receiving the lowest mean score was item 7 (on-going 
professional or in-service support: mean=3.35) while respondents mostly disagreed or strongly disagreed with item 28 (opportunity for professional development: $n=55,18.1 \%$ ). Overall, it might be suggested that respondents felt a clear distinction between the levels of support and staff development opportunity available to colleagues both internally and externally, the latter in particular clearly a cause for concern in terms of science curriculum implementation. Comments attracted from the wider NPSS (England) included:

'Provide regular, free, in-service provision within schools to keep knowledge up to date. Ensure that this is available for all classroom teachers rather than simply science co-ordinators who have this expertise already.'

'As science co-ordinator I have been on many courses. There is little or no time for feedback or evaluation and implementation. This needs to be done, to get the best value from the course.'

'Provide the funding for teachers to attend more local courses and inset training in order to improve confidence and knowledge and awareness of new developments in science pedagogical practice.'

\section{Exploratory analyses of data by subgroup}

In addition to considering each of the 7 individual scales of the SCIQ as a single unit of analysis, it was also considered appropriate to analyse the questionnaire data in terms of certain respondent characteristics themselves. These included sex, role in school, specialism when training, school size, years' teaching experience, in-service history and geographical region. Outcomes are summarised as shown (Table 6). Readers are, once again, advised to be mindful of the assumptions and limitations attached to the data transformations involved prior to statistical analysis and to the inevitable reductions in sample size associated with the different subgroups involved.

\section{[Insert Table 6 as close to here as possible.]}

No statistically significant differences were found across the scales with data analysed by sex or size of school. Interestingly, however, a clear distinction emerged witnessed almost exclusively in a relationship between the 3 'intrinsic' scales and geographical region and the 4 'extrinsic' scales and role in school, specialism when training, years' teaching experience and in-service history. In more detail: 
- Analysis of responses by geographical region found significant differences across the six partnership clusters involved in respondents' perceptions of professional knowledge (means 3.61 to 3.94), professional attitude and interest (means 3.78 to 4.12) and professional adequacy (means 3.62 to 4.02 ). This outcome was not anticipated and may be of possible interest and concern at a national level. It is certainly a finding worthy of further careful investigation.

- Analysis of responses by role in school found significant differences in respondents' perceptions of resource adequacy, school ethos and professional support. Outcomes were consistent and as might be expected in each case with head teachers responding more favourably than science coordinators and class teachers in that order (resource adequacy means 4.18 to 3.73; school ethos means 4.36 to 4.02; professional support means 4.12 to 3.68 ). This perhaps draws attention to certain 'realities' of school life and the different lenses through which teachers and others operating at different levels within schools view the day to day challenges they face.

- Analysis of responses by specialism at training found significant differences in respondents' perceptions of professional knowledge and time. Perhaps surprisingly, those who had not specialised in primary science at training responded more favourably than those who had (means 3.87 and 3.70) and time (means 3.63 and 3.34). The reasons for this are not clear but might tentatively include higher levels of critical reflection and a greater appreciation of the 'issues' attached to primary science among those individuals holding curriculum responsibility.

- Analysis of responses by experience found a significant difference in respondents' perceptions of professional support. Outcomes were consistent with those with more teaching experience responding consistently more favourably than those with less (mean of NQTs 3.54 to mean over 25 years' experience 3.97). Similarly, those teaching for more than 10 years and who had qualified before the introduction of new science training regulations (DfEE Circular 4/98 1998) responded more favourably than those who had qualified after (means 3.84 and 3.69). While these findings are relatively easy to interpret and understand, reflecting as they do the confidence which comes with experience itself, it might be taken as disappointing that those 'generalists' trained within perhaps a more rigorous regime to others did not feel more positive.

- Analysis of responses by in-service training found, as expected, significant differences in respondents' perceptions of resource adequacy and professional support. Outcomes were consistent in each case with those who had undertaken in- 
service training within three years prior to the survey, either at school, within the Local Authority or at Science Learning Centres, responding more favourably than those who had not (resource adequacy means 3.94 and 3.75; professional support means 3.92 and 3.66). The importance of in-service is clear.

\section{Summary and conclusions}

The National Curriculum has been with teachers and others in England since 1989. With an initial status as one of three 'core' subjects alongside English and mathematics, primary science has quite possibly attracted more attention than any other curriculum area, at least in terms of the confidence, competence and curricular expertise of teachers. With the reason for this almost certainly lying within the intrinsic and extrinsic challenges attached to learning science itself (e.g. Millar 1991, 1997), primary science remains, even to this day, relatively 'unfamiliar' to the primary 'generalist' who continues to 'struggle' with its often counter-intuitive and non-spontaneous nature and the more technical requirements associated with its practice. Despite three subsequent revisions to the science curriculum since 1989, each praised and contested in its own way, and with yet a further revision on the horizon, teachers have nevertheless embraced science through nothing short of their professionalism, dedication and hard work at the chalk-face. In this work, itself arising out of the more recent NPSS (England) involving 303 primary practitioners working in 206 schools across six geographically diverse regions of the country, and perhaps a last 'benchmark' of its kind before new statutory requirements inevitably come into force, it is evident that while many of the challenges associated with primary science remain, progress continues to be made with outcomes considered both positive and encouraging.

In its first fully documented 'outing' in the UK, including a re-assessment of its validity and reliability for use within a different cultural context, the Science Curriculum Implementation Questionnaire (SCIQ) appears to have demonstrated itself to be a valuable instrument with which to probe, measure and quantify the 'direction' and relative 'strength' of curriculum 'feeling' associated with its own 7 scales. Making full use of the SCIQ, certain personal or 'intrinsic' and environmental or 'extrinsic' factors were identified as more or less inhibiting curriculum implementation and delivery than others and for certain subgroups within the sample itself. It would therefore also appear to be a 'sensitive' instrument lending some credibility for its use not only as a 'tool' for evaluating science education provision nationally as here, but for providing an evidence-base for professional dialogue, strategic planning and decision making for overall school improvement locally and regionally. Despite advantages in its ease of use, analytical strengths and 'cost-effectiveness', the SCIQ is not without its 
limitations. As an instrument designed to measure and quantify the 'direction' and relative 'strength' of curriculum 'feeling', it nevertheless provides no information whatsoever in terms of how respondents understand what is presented before them or exactly what they mean when responding. In addition, the SCIQ, despite its 'range', can never claim to capture anything but the briefest glimpse of the nature of how teachers work and how schools operate, much if which actually lies beyond the scope of its 49 individual items (some of which within and between individual sales might also be considered insufficiently differentiated). Respondents, as indicated, are also required to consider how they themselves perceive how well colleagues and schools are responding to the demands of the primary science curriculum, with science presented as one undifferentiated entity, perceptions which assume a degree of professional judgement which cannot be independently verified or placed under further scrutiny. Nevertheless, the SCIQ is considered a valuable addition to the small range of questionnaires of its type (e.g. Pell and Jarvis 2003) if used with care or extended to collect qualitative data and other information as was the case here within the broader NPSS (England).

Within the additional limitations of the design of the NPSS (England), including representativeness, typicality and how the data collected were transformed and manipulated, overall exploratory findings can be represented in something of a hierarchical ordering of scales from least inhibiting to most as reflected in the response profiles and mean and median scores presented earlier:

- school ethos (least inhibiting);

- professional attitude and interest;

- professional adequacy;

- resource adequacy;

- professional knowledge;

- professional support;

- time (most inhibiting).

At a further level of detail, and considering those individual items from within each scale receiving the most favourable responses, science emerged clearly as a reasonably well acknowledged and important subject within the curriculum and a subject which most teachers felt positive towards and competent in 'delivering'. In terms of support, the resources available to teach science were generally considered readily accessible and well organised and the time available to teach requirements was, for many, at least adequate. At 
the opposite and less well received ends of each scale, many respondents felt less certain about the elevated profile of science as a 'core' subject and that the emphasis on science as a curriculum area was sometimes adversely influenced by school ethos. In terms of curricular expertise, pedagogical content knowledge was identified as the least well developed area of curricular expertise, itself perhaps impacting on levels of preparation, adaptability, creativity and confidence. While resources were generally considered accessible and well organised, these were thought not always well managed or maintained or sufficient in terms of type or abundance. Perhaps importantly, many respondents considered both the internal and external support for staff development mixed and many also considered time problematic with not enough allocated to science in the school week thus bringing it into conflict with other curriculum demands. Interestingly, and according to Boyle and Bragg 2005), while as many as 8 hours might be devoted to science in an average week, this was only fractionally more than the time devoted to each of the foundation subjects of the curriculum and less than half as much as that devoted to English and mathematics.

Exploratory analyses of the data by subgroup using the SCIQ showed no significant differences in the responses of male and female participants or by size of school where there may have been in the past. Perhaps not surprisingly, those respondents occupying senior management positions, those having longer service records and those having participated in in-service training at school or beyond looked upon science curriculum implementation and delivery in certain aspects more favourably than others. Most surprisingly, particularly given attempts to level the educational playing field with an entitlement for all accessed by way of a National Curriculum, findings revealed a significant geographical variation in the perception of personal or 'intrinsic' across the six geographically diverse regions involved. Of course, these and all other findings arising here should be investigated more fully before generalising or speculating too widely.

After over 20 years of primary science in the National Curriculum, however, there remains a strong sense, as presented here and elsewhere, of continued dissatisfaction among a sufficient proportion of teachers and others in key factors associated with effective implementation and delivery. To date, of course, no simple solution to this dissatisfaction and the factors giving rise to it has ever been found. As Shulman (1986, 1987), in addressing the problem of curricular expertise and 'knowledge growth' among teachers in general, asked: 'What are the sources of teacher knowledge?', 'What does a teacher know and when does he or she come to know it?' and 'How is new knowledge acquired and a new knowledge base achieved?'. Taking Shulman's 'knowledge' in its broadest sense, the 
answers, he suggested, lay in training, meaningful scholarly activity, the experience, wisdom and reflection of practice itself, the experience of working in different educational contexts, and being aware of educational ends, purposes and values. Indeed, pre-service and inservice education and training, together with teachers working to help each other in communities of practice, would seem the most obvious places to look and such places are frequently referred to in the science education literature. But as mentioned earlier in this work, the education and training of teachers and others in primary science has never been entirely effective. Among the many issues raised by Shallcross and Spink (2002), for example, models of initial teacher education and training are all too often mixed and varied and student teachers, despite more standardisation in overall provision, can often find themselves in environments where disproportionate amounts of time are spent on certain subjects over others or in certain preferred areas of science over others. They might also find themselves working closely with practitioners and mentors with very different attitudes towards science, not all of which are best suited to a training environment. In terms of how student teachers are assessed, different courses place different emphases on different things including, for example, subject knowledge, pedagogical content knowledge and curriculum knowledge, often at the expense of other important attributes including relationships with children. In short, student teachers can find themselves in environments spanning all possible outcomes determined by the SCIQ scales here and others, not all of which might be considered 'healthy' with respect to primary science (Fig.1). Waters-Adams (2006) also reminds us that 'the influences of both tacit and espoused understandings of the nature [and philosophy] of science, [when] considered alongside teachers' beliefs about [science] education, teaching and learning, [can be powerful] determining factors in teachers' decisions about classroom strategies' and that this might lead to misplaced assumptions of both how things are 'done' and why. Other work prepared from the NPSS (England) commissioned on behalf of the Wellcome Trust found potentially worrying features and trends attached to in-service courses too (Authors 2008). While 39.9\% of the 303 respondents had undertaken in-service training at school or with their Local Authority in the three years prior to the survey, a disproportionate, amount of this uptake was by science coordinators alone with all of the issues raised and presented earlier over awareness, accessibility and affordability and how this training benefits colleagues. Only $4.9 \%$ respondents had participated in in-service training organised at Science Learning Centres. The most frequently encountered elements of in-service training undertaken by most respondents across all regions were scientific enquiry in a biological context $(28.1 \%)$ and assessment $(24.0 \%)$. The development of pedagogical content knowledge was relatively minor (15.7\%) as was the use of ICT in science (8.3\%). And most of the training elicited could only be described as 'generic' and 'diverse'. The apparent lack of consistency and 
coherency in the provision or uptake of training, in the absence of any clearly articulated regional or national strategy and targeted demand, is perhaps problematic and certainly another area worthy of further investigation.

As a final comment perhaps, there is much to support the view that improvement in curriculum implementation and delivery will only take place effectively if teachers and others themselves take ownership of curriculum and find themselves empowered to transform the curriculum to meet more local variation and demand. While there have certainly been moves in this direction in recent years, the influences of external forces driving curriculum change are still felt by many and teachers and others have often found themselves marginalised and with little voice over matters which impact on their day to day lives. Independent evaluative studies from the Leverhulme Primary Project (e.g. Carré and Carter 1990, 1993) to the Primary Horizons project (Murphy et al. 2005, 2007) to the NPSS (England) (Authors et al. 2007, 2009) have been relatively consistent in their findings, highlighting positive as well as challenging impacts associated with the development of primary science and, short of more radical curriculum reform itself, providing valuable insight into where the focus of attention might lie. If indeed, as these and many other authors continue to point out that pre-service and in-service education hold the key, then we still require good models of research-informed and evidence-based practice to support this idea, models which are inclusive, flexible and balanced, and models which promote lifelong learning. Whatever the future for primary science, in England as well in the other home nations across the UK, we can only wait and see.

\section{Acknowledgements}

This work would not have been possible without the assistance of Lois Kelly (Liverpool Hope University), Graham Peacock (Sheffield Hallam University), Dan Davies (Bath Spa University), Rob Bowker (University of Exeter) and Sarah James (University of Hull) who gave up their time freely to help with data collection. The authors also acknowledge the financial assistance of the School Of Culture, Education and Innovation, Authors' institution.

\section{References}

Abd-El-Khalick, F. and Lederman, N.G. (2000) Improving science teachers conceptions of the nature of science: a critical review of the literature. International Journal of Science Education, 22(7), 665-701. 
Abell, S.K. and Lederman, N.G. (eds.)(2007) Handbook of research on science education. New Jersey: Lawrence Erlbaum Associates.

American Association for the Advancement of Science (1993) Benchmarks for science literacy: Project 2061. Oxford: Oxford University Press.

Barber, M. and Graham, D. (eds.) (1993) Sense, nonsense and the National Curriculum. London: Falmer.

Black, P. (1995a) 1987 to 1995: The struggle to formulate a National Curriculum for science in England and Wales. Studies in Science Education, 26, 159-88.

Black, P. (1995b) Curriculum and assessment in science education: The policy interface. International Journal of Science Education, 17(4), 453-69.

Boyle, B. and Bragg, J. (2005) No science today: The demise of primary science. Curriculum Journal, 16(4), 423-37.

Brighouse, T. and Moon, B. (eds.) (1990) Managing the National Curriculum: some critical perspectives. London: Longman.

Carré, C. and Carter, D. (1990) Primary teachers' self-perceptions concerning implementation of the National Curriculum in science in the UK. International Journal of Science Education, 12(4), 327-41.

Carré, C. and Carter, D. (1993) Primary teachers' self-perceptions concerning implementation of the National Curriculum in science in the UK-revisited. International Journal of Science Education, 15(4), 457-70.

Department for Education/Welsh Office (1995) Science in the National Curriculum. London. HMSO.

Department of Education and Science (1978) Primary education in England: a survey by HM Inspectors of schools. London: HMSO.

Department of Education and Science/Welsh Office (1989) Science in the National Curriculum. London: HMSO.

Department of Education and Science/Welsh Office (1991) Science in the National Curriculum. London: HMSO.

Department of Education and Science/Welsh Office/Department of Education for Northernlreland (1988) Science at age 11: a review of APU survey findings 1980-84. London: HMSO.

DfEE (Department for Education and Employment)(1998) Teaching: high status, high standards. Requirements for courses of Initial Teacher Training (Circular 4:98, Annex E). London: HMSO. 
DfEE/QCA (Department for Education and Employment/Qualifications and Curriculum Authority) (1999) Science: The National Curriculum for England. London: HMSO.

Field, A. (2009) Discovering statistics using SPSS. London: SAGE.

Fortune, J., Peters, G. and Rawlinson-Winder, L. (1993) Science education in English and Welsh primary schools: A system study. Journal of Curriculum Studies, 25(4), 359-69.

Fullan, M. (1992) Successful school improvement. Buckingham: Open University Press.

Harlen, W. (1992) Research and the development of science in the primary school. International Journal of Science Education, 14(5), 491-503.

Harlen, W. and Holroyd, C. (1997) Primary teachers' understanding of concepts of science: impact on confidence and teaching. International Journal of Science Education, 19(1), 93105.

Authors (2008) National Primary Science Survey (England): In-service training audit. London: Wellcome Trust. [Available at:

www.wellcome.ac.uk/stellent/groups/corporatesite/@msh_peda/documents/web_document/ wtd039296.pdf.]

House of Commons Education Committee (HCEC) (1995) Science and technology in schools. London: HMSO.

Holroyd, C. and Harlen, W. (1996) Primary teachers' confidence about teaching science and technology. Research Papers in Education, 11(3), 323-35.

Jarvis, T., Pell, A. and McKeon, F. (2003) Changes in primary teachers' science knowledge and understanding during a two-year in-service programme. Research in Science and Technological Education, 21(1), 17-42.

Kelly, A.V. (1994) The National Curriculum: a critical review. London: Paul Chapman.

Kinder, K. and Harland, J. (1991) The impact of INSET: the case of primary science. Slough: NFER.

Kruger, C., Summers, M. and Palacio, D. (1990) INSET for primary science in the National Curriculum in England and Wales: are the real needs of teachers perceived? Journal of Education for Teaching, 16(2), 133-46.

Lawton, D. (1992) Education and politics in the 1990s: conflict or consensus? London: Falmer.

Layton, D. (1973) Science for the people: the origins of the school science curriculum in England. London: Allen and Unwin. 
Author (2005) 'The growth is there - but it's not that evident, is it!: a study in science delivery improvement'. Journal of Science Teacher Education, 16(2), 121-39.

Author (2005) 'It's more than knowing the science': a case study in elementary science curriculum review. Canadian Journal of Mathematics, Science and Technology Education, 5(2), 170-86.

Author (2006) 'I want to enable teachers in their change': exploring the influence of a superintendent on science delivery. Canadian Journal of Educational Administration and Policy, 22, 1-23.

Author and Fisher, D.L. (2004) The application of a primary science curriculum evaluation questionnaire. Research in Science Education, 34, 55-70.

Author and Fisher D.L. (2005) The development and validation of a primary science curriculum delivery evaluation questionnaire. International Journal of Science Education, 27(5), 593-606.

Author and Renaud, R. (2009) Pilimmaksarniq: working together for the common good in science curriculum development and delivery in Nunavut. Canadian Journal of Science, Mathematics and Technology Education, 9(3), 154-72.

Author, Stoeber, R. and Renaud, R. (2007) The development, validation and application of a science delivery evaluation instrument for francophone-minority settings. Canadian Journal of Mathematics, Science and Technology Education, 7(4), 337-55.

Lunn, S. 2002. 'What we think we can safely say ...' : Primary teachers' views of the nature of science. British Educational Research Journal, 28(5), 649-72.

Macdonald, A., Palsdottir, A. and Thorolfsson, M. (2008) Changing constraints on science teaching activity in Icelandic schools. Paper presented at the European Science Education Research Association conference, Malmo, Sweden. [Available at: starfsfolk.khi.is/allyson/step/iceland-esera-final-paper110808.doc.]

Millar, R. (1991) Why is science hard to learn? Journal of Computer Assisted Learning, 7, 66-74.

Millar, R. (1997) Science education for democracy: what can the school curriculum achieve? In: R. Levinson \& J. Thomas (eds.) Science today: problem or crisis? London: Routledge. 87-101.

Ministry of Education (1993) Science in the New Zealand curriculum. Wellington: Learning Media.

Ministry of Education (2007) The New Zealand Curriculum Online.Wellingtopn: learning Media. [Available at: http://nzcurriculum.tki.org.nz] 
Moon, B. (1994) The National Curriculum: origins, context and implication. In: A. Pollard and J. Bourne (eds.) Teaching and learning in the primary school. Milton Keynes: Open University Press. 172-183.

Murphy, C., Beggs, J. and Russell, H. (2005) Primary horizons: Starting out in science. London: Wellcome Trust.

Murphy, C., Neil, P. and Beggs, J. (2007) Primary science teacher confidence revisited: ten years on. Educational Research, 49(4), 415-30.

National Research Council (1996) National science education standards. Washington: National Academy Press.

National Governors Association/Council of Chief State School Officers (2010) The Common Core State Standards. Washington: National Academy Press. [Available at: www.corestandards.org]

Newton, D. P. and Newton, L. D. (2000) Do teachers support causal understanding through their discourse when teaching primary science? British Educational Research Journal, 26(5), 599-13.

Oakley, D. (1993) A National Curriculum for science. In: R. Sherrington (ed.) ASE science teachers' handbook (primary), Trowbridge: Redwood. 17-36.

Office for Standards in Education (Ofsted) (2002) Science in primary schools. London: Ofsted.

Office for Standards in Education (Ofsted) (2008) Success in science. London: Ofsted.

Osborne, J. and Simon, S. (1996) Primary science: past and future directions. Studies in Science Education, 26, 99-147.

Owens, R.G. (1995) Organizational behavior in education. Boston: Allyn and Bacon.

Parker, J. (2004) The synthesis of subject and pedagogy for effective learning and teaching in primary science education. British Educational Research Journal, 30(6), 819-38.

Parker, J. and Haywood, D. (1998) The Earth and beyond: developing primary teachers' understanding of basic astronomical events. International Journal of Science Education, 20(5), 503-520.

Parker, J. and Haywood, D. (2000) Exploring the relationship between subject knowledge and pedagogic content knowledge in primary teachers' learning about forces. International Journal of Science Education, 22(1), 89-111.

Parker, J. and Spink, E. (1997) Becoming science teachers: an evaluation of the initial stages of primary teacher training. Assessment in Higher Education, 22(1), 17-31.

Payne, K. and Author (2002) Systematic curriculum review: A procedure for analysis. New Zealand Principal -Te Temuaki O Aotearoa, 18 (2), 30-33. 
Pell, A. and Jarvis, T. (2003) Developing attitude to science education scales for use with primary teachers. International Journal of Science Education, 25(10), 1273-95.

Pine, K., Messer, D. and St.John, K. (2001) Children's misconceptions in primary science: a survey of teachers' views. Research in Science and Technological Education, 19(11), 79-96.

Parliamentary Office for Science and Technology (PoST) (2003) Postnote: Primary science. London: Parliamentary Office for Science and Technology.

Qualter, A. (1999) How did you get to be a good primary science teacher? Westminster Studies in Education 22: 75-86.

Richards, C and Holford, D. (eds.)(1983) The teaching of primary science: policy and practice. London: Falmer.

Ritchie, R. (1996) Science in the National Curriculum. In: D. Coulby and S. Ward (eds.) The primary core curriculum: policy into practice. London, Cassell. 53-70.

Rose, J. (2009) Independent review of the primary curriculum: final report. London: DCSF Publications.

Russell, T., Bell, D., McGuigan, L., Qualter, A., Quinn, J. and Schilling, M. (1992) Teachers' conceptual understanding in science: needs and possibilities in the primary phase. Evaluation and Research in Primary Education, 6(2-3), 129-143.

Russell, T., Qualter, A. and McGuigan, L. (1995) Reflections on the implementation of National Curriculum science policy for the 5-14 age range: findings and interpretations from a national evaluation study in England. International Journal of Science Education, 17(4), 481-92.

Ryan, C. (2003) Becoming a teacher of primary science: Integrating theory and practice. Teachers and Teaching: theory and practice, 9(4), 333-49.

Shallcross, T. and Spink, E. (20020 How primary trainee teachers perceive the development of their own scientific knowledge: links between confidence, content and competence. International Journal of Science Education, 24(12), 1293-1312.

Author and Grace, M. (2004) Anecdote, opinion and whim: Lessons in curriculum development from primary science education in England and Wales. Research Papers in Education, 19(3), 293-321.

Authors (2007) National primary Science Survey (England). Lincolnshire: Bishop Grosseteste University College Lincoln. [Available at: (http://www.bishopg.ac.uk/ ?_id=865\&page=9.]

Author et al. (2009) Teacher preparation and the national primary science curriculum: a twentieth anniversary perspective. Research Papers in Education, 24(3), 247-63. 
Shulman, L.S. (1986) Those who understand: knowledge growth in teaching. Educational Researcher, 15 (2), 4-14.

Shulman, L.S. (1987) Knowledge and teaching: foundations of the new reform. Harvard Educational Review, 57(1), 1-22.

Smith, R. (1999) Piecing it together: Student teachers building their repertoire in primary science. Teaching and Teacher Education, 15, 301-14.

Sorsby, B.D. and Watson, E. (1993) Trainees' and teachers' confidence about their own science knowledge and skills in relation to the science national curriculum. British Journal of In-Service Education, 19(3), 43-9.

Summers, M. (1992) Improving primary school teachers' understanding of science concepts: theory into practice. International Journal of Science Education, 14(1), 25-40.

Summers, M. (1994) Science in the primary school: The problem of teachers' curricular expertise. Curriculum Journal, 5(2), 179-93.

Summers, M. and Kruger, C. (1994) A longitudinal study of a constructivist approach to improving primary school teachers' subject matter knowledge in science. Teaching and Teacher Education, 10(5), 499-519.

Traianou, A. (2006) Understanding teacher expertise in primary science: a sociocultural approach. Research Papers in Education, 21(1), 63-78. 


\begin{tabular}{lrr}
\hline Sex & & \\
male & 57 & $(18.8)$ \\
female & 246 & $(81.2)$ \\
Role & & \\
$\quad$ head teacher & 37 & $(12.2)$ \\
science coordinator & 82 & $(27.1)$ \\
class teacher & 184 & $(60.7)$ \\
Highest teaching qualification & & \\
Teaching certificate & 49 & $(16.2)$ \\
BEd & 78 & $(25.7)$ \\
BA/BSc with QTS & 57 & $(18.8)$ \\
PGCE (science as first degree) & 30 & $(9.9)$ \\
PGCE (other) & 89 & $(29.4)$ \\
Curriculum specialism at training & & \\
$\quad$ science & 75 & $(24.8)$ \\
other & 228 & $(75.2)$ \\
Teaching experience & & \\
NQT & 15 & $(5.0)$ \\
1-3 years & 31 & $(10.2)$ \\
4-10 years & 92 & $(30.4)$ \\
11-25 years & 110 & $(36.3)$ \\
over 25 years & 55 & $(18.2)$ \\
Type of school & & \\
primary & 261 & $(86.1)$ \\
junior & 14 & $(4.6)$ \\
infant & 28 & $(9.2)$ \\
Size of school & & \\
large (over 200 pupils) & 188 & $(62.1)$ \\
small (up to 200 pupils) & 115 & $(37.9)$ \\
In-service uptake & & \\
school or local authority (last three years) & 121 & $(39.9)$ \\
Science Learning Centre (last three years) & 15 & $(5.0)$ \\
\hline
\end{tabular}

Table 1 Frequencies and percentages of respondent characteristics $(n=303)$ 


\begin{tabular}{|c|c|c|c|}
\hline Scale & Items & Description & Example of item \\
\hline $\begin{array}{l}\text { Professional } \\
\text { knowledge }\end{array}$ & $1,8,15,22,29,36,43$ & $\begin{array}{l}\text { Perceptions of the knowledge } \\
\text { and understanding teachers } \\
\text { possess to deliver science as a } \\
\text { curriculum area }\end{array}$ & $\begin{array}{l}\text { Teachers at this school have a } \\
\text { sound knowledge of strategies } \\
\text { known to be effective for the } \\
\text { teaching of science }\end{array}$ \\
\hline $\begin{array}{l}\text { Professional attitude } \\
\text { and interest }\end{array}$ & $2,9^{r}, 16,23,30,37,44$ & $\begin{array}{l}\text { Perceptions of the attitudes and } \\
\text { interests held towards science } \\
\text { and the teaching of science as a } \\
\text { curriculum area }\end{array}$ & $\begin{array}{l}\text { Teachers at this school have a } \\
\text { positive attitude to the teaching } \\
\text { of science }\end{array}$ \\
\hline $\begin{array}{l}\text { Professional } \\
\text { adequacy }\end{array}$ & $4,11,18,25,32,39^{r}, 46^{r}$ & $\begin{array}{l}\text { Perceptions of teacher } \\
\text { confidence and preparation to } \\
\text { teach science as a curriculum } \\
\text { area }\end{array}$ & $\begin{array}{l}\text { Teachers possess the personal } \\
\text { confidence and skills necessary } \\
\text { to teach science competently }\end{array}$ \\
\hline Resource adequacy & $3,10,17,24,31^{r}, 38,45$ & $\begin{array}{l}\text { Perceptions of the value and } \\
\text { usefulness of existing equipment } \\
\text { and facilities for teaching } \\
\text { science as a curriculum area }\end{array}$ & $\begin{array}{l}\text { Teachers at this school have } \\
\text { ready access to science } \\
\text { materials and resources }\end{array}$ \\
\hline Time & $6^{r}, 13,20^{r}, 27,34,41,48^{r}$ & $\begin{array}{l}\text { Perceptions of the time available } \\
\text { for the preparation and teaching } \\
\text { of science as a curriculum area }\end{array}$ & $\begin{array}{l}\text { There is enough time in the } \\
\text { school week to do an adequate } \\
\text { job of teaching the requirements } \\
\text { of the science curriculum }\end{array}$ \\
\hline School ethos & $5,12,19,26,33^{r}, 40,47$ & $\begin{array}{l}\text { Perceptions of schools beliefs } \\
\text { towards and regard for science } \\
\text { as curriculum area }\end{array}$ & $\begin{array}{l}\text { Science is regarded as an } \\
\text { important subject in the school's } \\
\text { overall curriculum }\end{array}$ \\
\hline Professional support & $7,14,21,28,35,42,49$ & $\begin{array}{l}\text { Perceptions of the support } \\
\text { available to teach science from } \\
\text { both school and external } \\
\text { sources }\end{array}$ & $\begin{array}{l}\text { Teachers at this school have the } \\
\text { opportunity to undertake } \\
\text { professional development in } \\
\text { science }\end{array}$ \\
\hline
\end{tabular}

Table 2 Scales from the Science Curriculum Implementation Questionnaire ( ${ }^{r}$ denotes reverse-score item) 


\begin{tabular}{|c|c|c|c|c|}
\hline Scale & $\begin{array}{c}\text { Rotated factor } \\
\text { loadings }^{\mathrm{a}}\end{array}$ & $\begin{array}{c}\text { Inter-scale } \\
\text { correlations }^{\mathrm{b}}\end{array}$ & $\begin{array}{c}\text { Discriminant } \\
\text { validity }\end{array}$ & $\begin{array}{l}\text { Alpha } \\
\text { reliability }\end{array}$ \\
\hline Professional knowledge & $0.656-0.787$ & $0.402-0.847$ & 0.618 & 0.899 \\
\hline Professional attitude/interest & $0.525-0.700$ & $0.369-0.812$ & 0.616 & 0.890 \\
\hline Professional adequacy & $0.532-0.820$ & $0.405-0.847$ & 0.631 & 0.833 \\
\hline Resource adequacy & $0.618-0.811$ & $0.302-0.631$ & 0.479 & 0.912 \\
\hline Time & $0.677-0.856$ & $0.302-0.462$ & 0.385 & 0.915 \\
\hline School ethos & $0.553-0.749$ & $0.462-0.700$ & 0.437 & 0.899 \\
\hline Professional support & $0.426-0.648$ & $0.370-0.682$ & 0.572 & 0.859 \\
\hline
\end{tabular}

Table 3 Overall instrument validity and reliability ( ${ }^{a}$ based on 5 components reflecting the 7 scales; ${ }^{b}$ all inter-scale correlations significant, $p<0.001$ ) 


\begin{tabular}{|l|c|c|c|c|c|}
\hline & \multicolumn{4}{c|}{ Response (\%) } \\
\hline Science element & A & B & C & D & E \\
\hline Humans and other animals & 71.9 & 25.4 & 2.6 & 0.0 & 0.0 \\
\hline Life processes & 69.3 & 27.7 & 3.0 & 0.0 & 0.0 \\
\hline Living things and their environment & 67.7 & 28.4 & 4.0 & 0.0 & 0.0 \\
\hline Green plants & 65.0 & 30.4 & 4.6 & 0.0 & 0.0 \\
\hline Grouping and classifying materials & 63.4 & 31.4 & 4.3 & 1.0 & 0.0 \\
\hline Changing materials & 57.8 & 36.3 & 5.0 & 0.3 & 0.7 \\
\hline Variation and classification & 56.4 & 37.6 & 5.3 & 0.7 & 0.0 \\
\hline Light and sound & 53.5 & 38.3 & 7.6 & 0.3 & 0.3 \\
\hline Scientific enquiry & 52.1 & 39.9 & 7.3 & 0.3 & 0.3 \\
\hline Separating mixtures of materials & 49.5 & 39.9 & 8.9 & 1.0 & 0.7 \\
\hline Electricity & 48.5 & 42.6 & 8.3 & 0.3 & 0.3 \\
\hline Forces and motion & 44.2 & 44.2 & 10.6 & 0.7 & 0.3 \\
\hline The Earth and beyond & 43.6 & 44.6 & 10.2 & 1.3 & 0.3 \\
\hline
\end{tabular}

Table 4 Respondents' levels of self-perceived preparation to teach science ( $A=$ very well prepared; $B=$ =require some help from colleagues; $C=$ require some in-service support; $D=$ =require substantial in-service support; $E=$ may never feel prepared; $\mathrm{n}=303$ ) 


\begin{tabular}{|l|c|c|c|c|c|c|c|}
\hline Scale & $\begin{array}{c}\text { Mean } \\
\text { (SD) }\end{array}$ & Median & SA (5) & A (4) & N (3) & D (2) & SD (1) \\
\hline Professional knowledge & $\begin{array}{c}3.83 \\
(0.54)\end{array}$ & 3.86 & 14.2 & 57.9 & 24.2 & 3.6 & 0.1 \\
\hline Professional attitude/interest & $\begin{array}{c}4.02 \\
(0.56)\end{array}$ & 4.00 & 24.0 & 57.1 & 16.2 & 2.3 & 0.4 \\
\hline Professional adequacy & $\begin{array}{c}3.87 \\
(0.56)\end{array}$ & 3.86 & 20.7 & 51.8 & 22.3 & 4.7 & 0.6 \\
\hline Resource adequacy & $\begin{array}{c}3.83 \\
(0.72)\end{array}$ & 4.00 & 21.4 & 50.4 & 19.3 & 7.5 & 1.4 \\
\hline Time & $\begin{array}{c}3.56 \\
(0.83)\end{array}$ & 3.71 & 16.8 & 42.0 & 24.4 & 14.0 & 2.7 \\
\hline School ethos & 4.07 & 4.14 & 31.4 & 48.8 & 16.3 & 2.9 & 0.7 \\
\hline Professional support & $(0.62)$ & & & & & & \\
\hline
\end{tabular}

Table 5 Mean and median scores with percentage responses across all 7 items within each scale $(\mathrm{SD}=$ standard deviation; scale items reverse-scored where appropriate; $n=303$ ) 


\begin{tabular}{|c|c|c|c|c|c|c|c|}
\hline Scale & Sex & Role & Spec. & Size & Exp. & In-ser. & Geog. \\
\hline Professional knowledge & & & $0.034^{*}$ & & & & $0.011^{\mp}$ \\
\hline Professional attitude/interest & & & & & & & $0.017^{\mp}$ \\
\hline Professional adequacy & & & & & & & $0.003^{\mp}$ \\
\hline Resource adequacy & & $0.001^{\mp}$ & & & & $0.008^{*}$ & \\
\hline Time & & & $0.007^{\star}$ & & & & \\
\hline School ethos & & $0.007^{\ddagger}$ & & & & & \\
\hline Professional support & 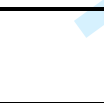 & $0.000^{\ddagger}$ & & & $\begin{array}{l}0.006^{\ddagger} / \\
0.014^{\ddagger}\end{array}$ & $0.000^{*}$ & \\
\hline
\end{tabular}

Table 6 Statistical analysis of responses by subgroup $(n=303 ; \neq=e x a c t$ probability, Kruskal-Wallis $\chi^{2}$; ${ }^{*}=$ exact probability, Mann-Whitney $U$ ) 


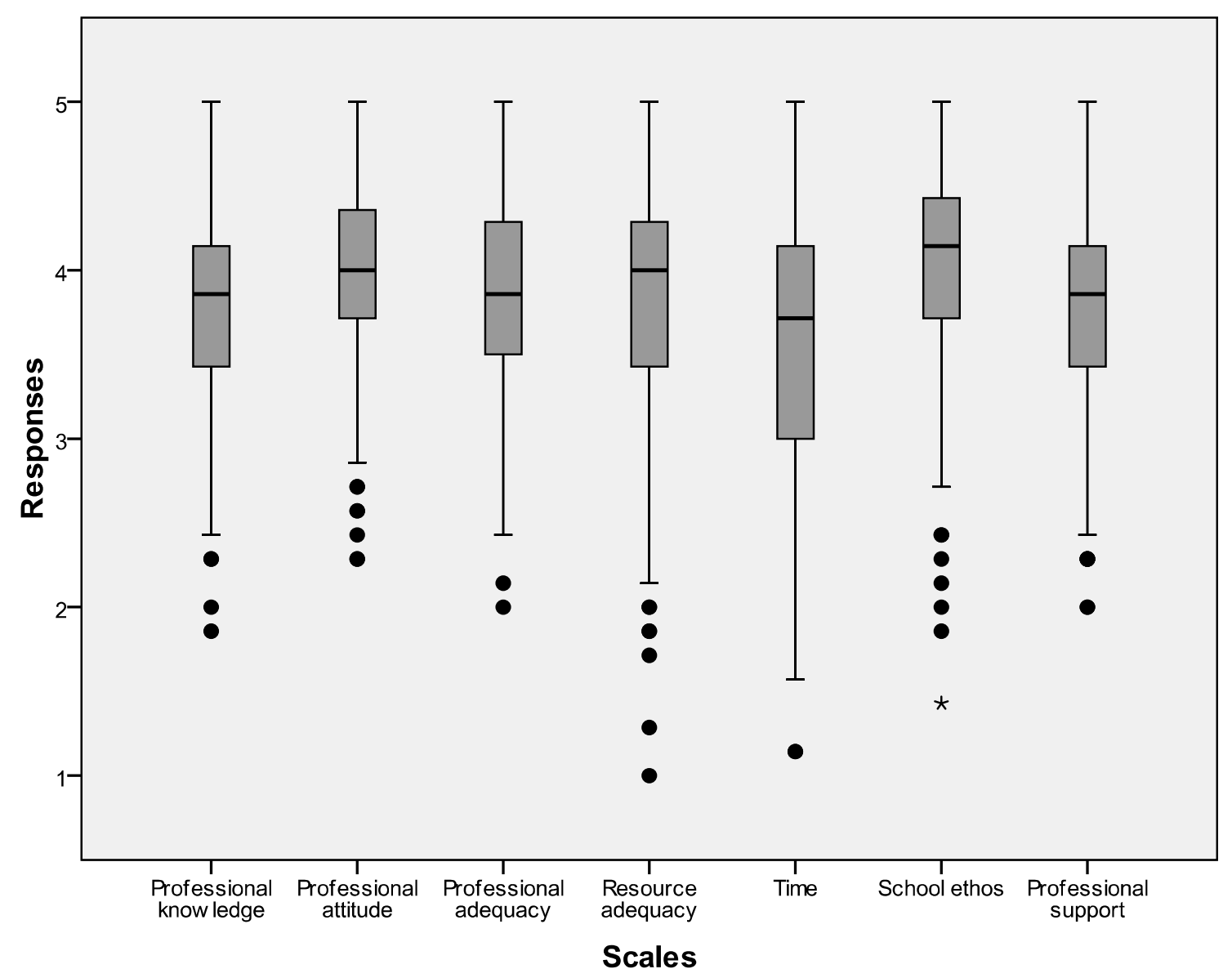

Fig.1 Box and whisker plots showing the median values and overall distribution of responses including outliers across each of the 7 scales $(n=303)$ 


\section{Appendix: Science Curriculum Implementation Questionnaire}

\section{How well do you think these statements describe the school in which you work?}

There are 49 items in this questionnaire. These items are statements which should be considered in the context of the school in which you work. Please provide a single response to each statement using the scale and criteria provided.

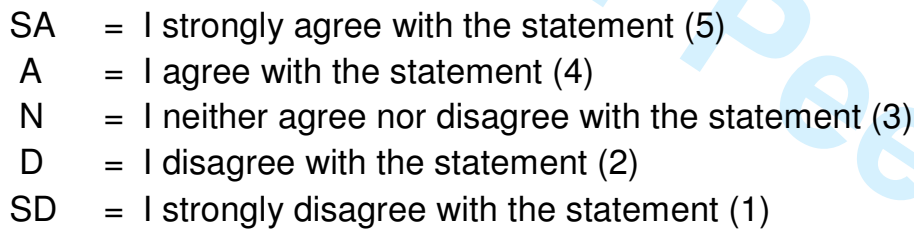

It is important here that the responses are your own and not the shared views of other colleagues.

\section{Circle your answer}

1. Teachers at this school have a good understanding of the science knowledge, skills and attitudes they are to promote in their teaching.

2. Teachers at this school have a positive attitude to the teaching of science.

SA A N D $\quad$ SD

3. The school is well resourced for the teaching of science.

SA A N D SD

4. Teachers at this school are adequately prepared to teach science.

5. The school's senior management team recognises the importance of science as a subject in the overall school curriculum.

6. There is not enough time allocated to science in the school week to fit science in properly.

7. Teachers at this school have the opportunity to receive on-going professional or in-service support for science.

$\begin{array}{lllll}\text { SA } & \text { A } & \text { N } & \text { D } & \text { SD } \\ \text { SA } & \text { A } & \text { N } & \text { D } & \text { SD } \\ \text { SA } & \text { A } & \text { N } & \text { D } & \text { SD } \\ \text { SA } & \text { A } & \text { N } & \text { D } & \text { SD } \\ \text { SA } & \text { A } & \text { N } & \text { D } & \text { SD }\end{array}$


8. Teachers at this school have a sound knowledge of strategies known to be effective for the teaching of science.

9. Teachers at this school are reluctant to teach science.

10. The school-based system of managing science resources is well maintained.

11. Teachers at this school are confident science teachers.

12. The school's ethos positively influences the teaching of science.

13. There is enough time in the school week to do an adequate job of teaching the requirements of the science curriculum.

14. Support from colleagues is a positive factor in fostering the implementation of the science curriculum at this school.

15. Teachers at this school have a sound understanding of alternative ways of teaching scientific ideas to foster children's learning.

16. Teachers at this school have a strong motivation to ensure that science is taught at this school.

17. Teachers at this school have ready access to science materials and resources.

18. Teachers at this school are competent teachers of science.

19. The school places a strong emphasis on science as a curriculum area.

20. The school curriculum is crowded, science suffers because of this.

21. The support of colleagues evident in this school is important in fostering capabilities in teachers who find science difficult to teach.

22. Teachers at this school are secure in their knowledge of science concepts pertinent to the science curriculum.

23. Teachers at this school have a positive attitude to science as a subject in the school curriculum.

24. The facilities at this school promote the teaching of science.
SA $\quad$ A $\quad$ N $\quad$ D $\quad$ SD
SA $\quad$ A $\quad$ N $\quad$ D $\quad$ SD
SA $\quad$ A $\quad$ N $\quad$ D $\quad$ SD
SA $\quad$ A $\quad$ N $\quad$ D $\quad$ SD
SA $\quad$ A $\quad$ N $\quad$ D $\quad$ SD
SA $\quad$ A $\quad$ N $\quad$ D $\quad$ SD
SA A N D $\quad$ SD
SA A N D SD
SA A N $\quad$ D $\quad$ SD
SA A N D SD
SA A N D SD
SA A N $\quad$ D $\quad$ SD
SA A N $\quad$ D $\quad$ SD
SA $\quad$ A N N $\quad$ D
SA A N $\quad$ D $\quad$ SD
SA A N $\quad$ D $\quad$ SD
SA A N $\quad$ D $\quad$ SD 
25. Teachers at this school possess the personal confidence and skills necessary to teach science competently.

26. Science has a high profile as a curriculum area at this school.

SA $\quad$ A $\quad$ N $\quad$ D $\quad$ SD

27. There is enough time in the school timetable to teach science.

SA $\quad$ A $\quad$ N $\quad$ D $\quad$ SD

28. Teachers at this school have the opportunity to undertake professional development in science.

SA $\quad$ A $\quad$ N $\quad$ D $\quad$ SD

29. Teachers at this school possess the necessary science subject knowledge to be a good science educator.

SA $\quad$ A $\quad$ N $\quad$ D $\quad$ SD

29. Teachers at this school possess the necessary science subject knowledge to be a good science educator.

SA $\quad$ A $\quad$ N $\quad$ D $\quad$ SD

30. Science is a subject at this school that teachers want to teach.

SA $\quad$ A $\quad$ N $\quad$ D $\quad$ SD

31. The science resources at the school are poorly organised.

32. Teachers at this school have positive perceptions of their competence as science educators.

33. Science has a low status as a curriculum area at this school.

34. Teachers at this school believe that there is adequate time in the overall school timetable to teach science.

35. Teachers at this school are supported in their overall efforts to teach science.

36. Teachers at this school have a good understanding of their children's background knowledge relevant for the teaching of science.

37. Teachers at this school have a positive attitude to science as a learning area.

38. The equipment that is necessary to teach science is readily available.

39. Teachers at this school are inadequately prepared to teach to the requirements of the national science curriculum.

40. Science as a curriculum area is valued at this school.

SA A N $\quad$ D $\quad$ SD

SA $\quad$ A $\quad$ N $\quad$ D $\quad$ SD

SA A N D SD

SA A N $\quad$ D $\quad$ SD

SA A N D SD

SA A N $\quad$ D $\quad$ SD

SA A N $\quad$ D $\quad$ SD

SA $\quad$ A $N$ N

SA A N $\quad$ D $\quad$ SD

SA A N $\quad$ D $\quad$ SD

41. Teachers at this school have the time to effectively deliver the requirements of the national science curriculum.

SA $\quad$ A $\quad$ N $\quad$ D $\quad$ SD 

42. The senior management team of the school actively supports science as a curriculum area.
SA $\quad$ A $\quad$ N $\quad$ D $\quad$ SD
43. Teachers at this school have a clear understanding of the science curriculum.
SA $\quad$ A $\quad$ N $\quad$ D $\quad$ SD
44. Teachers at this school are motivated to 'make science work' as a curriculum area.
SA $\quad$ A $\quad$ N $\quad$ D $\quad$ SD
45. The school has adequate science equipment necessary for the teaching of science.
SA $\quad$ A $\quad$ N $\quad$ D $\quad$ SD
46. Teachers at this school have a negative self-image of themselves as regards their ability to teach science.
SA $\quad$ A $\quad$ N $\quad$ D $\quad$ SD
47. Science is regarded as an important subject in the school's overall curriculum among teachers.
SA $\quad$ A $\quad$ N $\quad$ D $\quad$ SD
48. Lack of time is a major factor inhibiting the delivery of science at this school.
SA $\quad$ A $\quad$ N $\quad$ D $\quad$ SD
49. Leadership in science at this school fosters capabilities in those who require support in teaching science.
SA $\quad$ A $\quad$ N $\quad$ D $\quad$ SD 